\title{
ZAKOŃCZENIE
}

Prezentowany numer tematyczny „Studiów nad Rodziną” został poświęcony problematyce profesjonalizacji usług asystenckich i opiekuńczych dla starszych osób niesamodzielnych, obowiązującym i proponowanym rozwiązaniom prawnym, uwarunkowaniom demograficznym, standardom usług oraz kształcenia opiekunów i opiekunek na tle europejskim. W dobie starzenia się społeczeństwa, a tym samym wzrostu liczby osób niepełnosprawnych i niesamodzielnych, obarczonych wieloma chorobami przewlekłymi i problemami zdrowotnymi, istotnym jest zapewnienie odpowiedniego wsparcia oraz szybko dostępnych form pomocy i opieki.

Jak zostało zasygnalizowane we Wstępie, wydanie numeru specjalnego „Studiów nad Rodziną" wpisuje się w konsultacje środowiskowe związane z podejmowanymi działaniami w ramach projektu pt. „Profesjonalizacja usług asystenckich i opiekuńczych dla osób niesamodzielnych - nowe standardy kształcenia i opieki”, które uzupełniają pozostałe aktywności projektowe. W niniejszym numerze czasopisma uwzględniona została interdyscyplinarna płaszczyzna analizy głównej problematyki, co miało na celu zwrócenie uwagi na potrzebę zróżnicowanego podejścia w działaniach wspierających na rzecz osób starszych i niesamodzielnych.

W ramach działań projektowych wypracowane zostały kryteria oceny stopni niesamodzielności, stanowiące podstawę zakresu usług objętych standaryzacją. Została przedstawiona propozycja modelu opieki nad osobami niesamodzielnymi oraz opracowano główne założenia standardów usług i standardów kształcenia opiekunów.

\section{Standardy usług}

Wymiar społeczny, przyczyny oraz koszty społeczne i indywidualne związane z zabezpieczeniem skutków niesamodzielności, wywołują potrzebę standaryzowanego i monitorowanego działania. Standaryzacja usług asystenckich 
i opiekuńczych jest oparta na hierarchicznym modelu kompensacyjnym i koncepcji opieki kompensacyjnej i obejmuje trzy standardy wsparcia':

1. Standard usług dla osób z umiarkowaną niesamodzielnością (pierwszy stopień niesamodzielności - wsparcie w formie usług asystenckich; kod wsparcia A - asysta; usługi realizowane w dni robocze w wymiarze nie większym niż 2 godziny dziennie oraz usługi teleopieki - kod wsparcia T);

2. Standard usług dla osób ze znaczną niesamodzielnością (drugi stopień niesamodzielności - wsparcie w formie różnych usług pomocowych; kod wsparcia $\mathrm{P}$ - pomoc; usługi realizowane $\mathrm{w}$ dni robocze $\mathrm{w}$ wymiarze nie większym niż 4 godziny dziennie;

3. Standard usług dla osób z całkowitą niesamodzielnością (trzeci stopień niesamodzielności - wsparcie w formie usług opiekuńczych; kod wsparcia $\mathrm{O}$ - opieka całkowita; usługi realizowane codziennie w wymiarze nie większym niż 6 godzin dziennie.

Standardy usług asystenckich i opiekuńczych, są zbiorem profesjonalnych zaleceń dotyczących postępowania opiekuńczego wobec osób niesamodzielnych. Są one zbieżne z praktyką pielęgniarską w zakresie pielęgnowania oraz opieki nad osobami, które stały się niesamodzielne w związku z urazem, chorobą przewlekłą lub podeszłym wiekiem. Uwzględnia się tu także akceptowany społecznie niezbędny zakres wsparcia osoby niesamodzielnej w prowadzeniu gospodarstwa domowego i funkcjonowaniu w społeczeństwie².

Standardy opieki stanowią narzędzie źródłowe przy diagnozowaniu potrzeb i podejmowaniu decyzji opiekuńczych, odpowiednio do potrzeb oraz oczekiwań osoby niesamodzielnej i/lub jej osoby bliskiej, która pełni rolę opiekuna faktycznego. Stanowią one wzorce dla interwencji opiekuńczych i zwracają także uwagę na niezbędne dla jakości opieki kompensacyjnej odpowiednie zasoby takie jak kwalifikacje kadry (znajomość technik pracy), sprzęt wspomagający i wyroby medyczne. Standardy opieki powinny być stosowane na tyle elastycznie, by móc pogodzić oczekiwania osoby niesamodzielnej i jej rodziny co do zakresu wsparcia odpowiednio do stopnia niesamodzielności i oczekiwania opiekuna co do warunków lokalowych w kontekście obowiązujących przepisów prawa (np. BHP)³.

\footnotetext{
Standardy usług asystenckich i opiekuńczych dla osób niesamodzielnych, Zespół realizatorów, Warszawa 2018; Założenia Standardów Usług przedstawiono na postawie informacji zawartych na stronie projektu pt. „Profesjonalizacja usług asystenckich i opiekuńczych dla osób niesamodzielnych - nowe standardy kształcenia i opieki”: http://www. aio.uksw.edu.pl/pl/node/460 (dostęp 18 listopada 2018 roku).

2 Tamże.

3 Tamże.
} 
Kierując się Standardami opieki, opiekun efektywnie kompensuje utraconą sprawność, wspiera i aktywizuje osobę niesamodzielną oraz jej rodzinę w dążeniu do wspólnego celu, którym jest możliwie duża samodzielność, a tym samym poprawa jakości ich życia. Standardy opieki nie ustanawiają odpowiedzialności prawnej ani też z niej nie zwalniają, jednak ich zastosowanie w praktyce jest dowodem na dołożenie należytej staranności i sprawowanie opieki opartej na aktualnej wiedzy o najlepszych praktykach opiekuńczych, które mają na celu poprawę jakości życia osoby niesamodzielnej. Standardy opieki powinny być uwzględniane przy opracowywaniu przez zarządzających oraz personel opiekuńczy zasad postępowania, procedur, programów edukacyjnych, ocen jakości opieki oraz zakresu dokumentowania, w tym dokumentacji elektronicznej ${ }^{4}$.

\section{Standardy ksztalcenia}

Misją opiekuna jest pomoc osobie niesamodzielnej w zaspokajaniu podstawowych potrzeb życiowych i wykonywanie tych czynności, które wykonywałaby ona samodzielnie, gdyby miała potrzebną siłę, wolę lub wiedzę, w taki sposób, żeby pomóc jej odzyskać samodzielność życiową w możliwie dużym zakresie. Opiekun osoby niesamodzielnej udziela także wsparcia osobie niesamodzielnej w prowadzeniu gospodarstwa domowego i funkcjonowaniu w społeczeństwie. Efektywnie kompensuje utraconą sprawność, wspiera i aktywizuje osobę niesamodzielną oraz jej rodzinę w dążeniu do wspólnego celu, którym jest możliwie duża samodzielność, a tym samym poprawa jakości ich życia. Jest to osoba, która pomaga swoim podopiecznym zaspokajać potrzeby bio-psycho-społeczne. Opiekun osoby niesamodzielnej to zawód zaufania publicznego. Absolwent kursu specjalistycznego „Opiekun osoby niesamodzielnej” powinien być przygotowany do wykonywania następujących zadań zawodowych ${ }^{5}$ :

1. rozpoznawanie możliwości oraz ograniczeń w funkcjonowaniu osoby niesamodzielnej;

2. rozpoznawanie i ocena stanu psychicznego osoby niesamodzielnej;

3. rozpoznawania i interpretowania sytuacji społecznej, warunków życia, relacji z rodziną i środowiskiem lokalnym osoby niesamodzielnej;

\footnotetext{
4 Tamże.

5 Założenia „Standardów kształcenia” przedstawiono na postawie informacji zawartych na stronie projektu pt. „Profesjonalizacja usług asystenckich i opiekuńczych dla osób niesamodzielnych - nowe standardy kształcenia i opieki”: http://www.aio.uksw.edu.pl/pl/ node/419 (dostęp 18 listopada 2018 roku).
} 
4. dobieranie metod, technik, narzędzi i form realizacji działań opiekuńczo-wspierających do sytuacji życiowej, stanu zdrowia, rozpoznanych problemów i potrzeb osoby niesamodzielnej;

5. sprawowanie opieki nad osobą niesamodzielną oraz udzielanie jej wsparcia emocjonalnego;

6. wykorzystywania zasobów indywidualnych, środowiska rodzinnego, instytucjonalnego i lokalnego w opiece nad osobą niesamodzielną;

7. wykonywanie podstawowych czynności pielęgnacyjnych na rzecz osoby niesamodzielnej;

8. pomoc w wykonywaniu podstawowych i złożonych czynności dnia codziennego osobie niesamodzielnej;

9. utrzymywania sprawności i aktywizowanie osoby niesamodzielnej;

10. wspieranie oraz motywowanie osoby niesamodzielnej do podejmowania aktywnych form spędzania czasu wolnego, rozwijających zainteresowania i usprawniających psychofizycznie oraz społecznie;

11. nawiązywanie, podtrzymywanie i rozwijanie współpracy z podmiotami działającymi na rzecz osoby starszej w środowisku lokalnym.

Problemy dotyczące osób niesamodzielnych regulowane są przez różnego rodzaju rozwiązania prawne określające uprawnienia dla danej osoby, a także obowiązki podmiotów prawa prywatnego oraz organów władzy publicznej. Analizy statusu osoby niesamodzielnej w kontekście Konstytucji Rzeczypospolitej Polskiej przedstawione zostały przez Aleksandrę Syryt w artykule pt. „Konstytucyjne podstawy ochrony osób niesamodzielnych". Zapisy ustawy najwyższej wyznaczają podstawy pozycji jednostki w państwie i określają ramy ochrony, którą władze publiczne zobowiązane są jej zapewnić.

System wsparcia osób starszych oraz potrzeby w zakresie opieki długoterminowej we Włoszech został zaprezentowany przez Sławomira H. Zarębę i Marcina Zarzeckiego jako modelowy przykład funkcjonowania wielowymiarowego rozwiązania sektora finansów publicznych. Przeprowadzone w artykule pt. „Analiza socjo-ekonomiczna systemu wsparcia osób starszych oraz potrzeb w zakresie opieki długoterminowej we Włoszech" studium systemu wsparcia osób starszych we Włoszech stanowi przedmiot zainteresowania publicznych i niepublicznych podmiotów organizujących profesjonalną pomoc i asystenturę dla osób starszych. Przedstawione w artykule rozwiązania funkcjonujące we Włoszech mogą być istotnym punktem odniesienia i porównania skuteczności zastosowanych form wsparcia.

Istotne znaczenie dla analizowanej problematyki dotyczącej profesjonalizacji usług asystenckich i opiekuńczych dla osób niesamodzielnych posiada przedstawienie „socjologicznego portretu” polskich seniorów oraz problemów związanych 
ze starzeniem się społeczeństwa w kontekście nowych zadań dla polityki rodzinnej. Małgorzata Szyszka w artykule pt. „Seniorzy i starzenie się w polskiej polityce rodzinnej" przedstawiła analizy tych kategorii problemów osób starszych, które stanowią współczesne wyzwania dla polityki społecznej i rodzinnej, a także różne instrumenty polityki rodzinnej mających na celu wsparcie i aktywizację osób w podeszłym wieku.

Istotną nowością podjętą przez Martę Luty-Michalak w artykule pt. „Demograficzne uwarunkowania zapotrzebowania na usługi asystenckie i opiekuńcze wśród osób starszych w Polsce" jest weryfikacja hipotezy o zmniejszających się możliwościach sprawowania opieki nad osobami starszymi przez członków najbliższej rodziny w świetle postępującego procesu starzenia się społeczeństwa polskiego w perspektywie czasowej do 2080 roku. Autorka zwróciła uwagę na fakt, iż proces ten implikuje wiele wyzwań, w tym także konieczność zapewnienia profesjonalnej opieki niesamodzielnym osobom starszym. Do walorów opracowania należy zaliczyć podjęcie próby przedstawienia głównych demograficznych uwarunkowań procesu starzenia się społeczeństwa polskiego, co ma istotna znaczenie w kontekście tworzenia standardów usług oraz kształcenia opiekunów osób niesamodzielnych.

Justyna Kurtyka-Chałas w artykule pt. „Indywidualne właściwości percepcji czasu u osób starszych z perspektywy badań własnych" przedstawiła wyniki przeprowadzonych badań, których wyniki wskazują na istnienie istotnych powiązań pomiędzy wybranymi postawami życiowymi a percepcją czasu u osób starszych. Poszukiwanie powiązań pomiędzy percepcją czasu w kategoriach metafor a postawami życiowymi to psychologiczna perspektywa problemu związanego z ogólnie pojętą sytuacją osób starszych. Jak już zostało zasygnalizowane, trudności w samodzielnym funkcjonowaniu osób starszych, będące uzasadnieniem konieczności działań asystenckich i opiekuńczych, mogą dotyczyć wielu obszarów życia osoby niesamodzielnej i jej rodziny, co wskazuje na potrzebę wieloaspektowego i kompleksowego podejścia w działaniach wspierających.

$\mathrm{W}$ artykule pt. „Wybrane potrzeby edukacji terapeutycznej osób z demencją starczą oraz ich rodzin" podjęta została analiza podstawowych problemów, które należy uwzględnić w toku edukacji terapeutycznej pacjentów z demencją starczą $\mathrm{i}$ ich rodzin. Anna Mirczak ukazała medyczne aspekty analizowanych zagadnień, dostarczając czytelnikowi przeglądu reprezentatywnych stanowisk oraz przedstawiając złożony charakter demencji jako nieuleczalnej choroby przewlekłej wywołującej szereg negatywnych konsekwencji fizycznych, psychicznych i społecznych.

Artykuł pt. „Samotność seniorów a rodzina. Wyzwania dla opieki profesjonalnej" podjęta została problematyka samotności osób starszych z uwzględnieniem jej rodzinnego kontekstu i związanych z tym wyzwań dla opieki profesjonalnej. 
Walorem opracowania jest analiza podstawowych czynników, które posiadają wpływ na przeżywanie osamotnienia w tym okresie życia (m.in. zakończenie aktywności zawodowej, zmiana pozycji i ról w rodzinie, zmniejszanie się sieci towarzyskiej i ograniczanie kontaktów społecznych, wdowieństwo). Poddanie analizie głównych przyczyn samotności seniorów, ze zwróceniem uwagi na rolę rodziny jako czynnika zmniejszającego ryzyko odczuwanej samotności, wskazuje na kwestie związane z potrzebą profesjonalnej opieki odpowiadającej na złożone potrzeby osób w podeszłym wieku.

Józef Młyński w artykule pt. „Hilfe für ältere Menschen im rahmen der Sozialarbeit in Polen" (Pomoc dla osób starszych w ramach pracy socjalnej w Polsce) zaprezentował główne formy pomocy kierowanej do osób starszych w ramach pracy socjalnej w Polsce, a także rolę pracownika socjalnego w zakresie wsparcia seniorów. Wyjaśnione zostały zarówno podstawowe zagadnienia teoretyczne, jak również główne instrumenty stosowane w praktyce wspierania tej grupy osób w systemie pomocy społecznej.

Współczesne przemiany rodziny (m.in. zmniejszanie się liczebności rodzin, związki nieformalne, aktywizacja zawodowa kobiet, migracje) prowadzą do potencjalnego spadku liczby rodzinnych opiekunów. Z punktu widzenia podmiotów świadczących usługi opiekuńcze wertykalizacja sieci rodzinnej jest jednym z najistotniejszych czynników wpływających na zwiększenie się liczby osób wymagających pomocy ze strony osób niespokrewnionych. $Z$ uwagi na przyszły szybki przebieg procesu podwójnego starzenia się ludności określenie skali zapotrzebowania na profesjonalne usługi asystenckie i opiekuńcze nad niesamodzielnymi osobami starszymi oraz standardy tych usług może stanowić z jednej strony wskazówkę odnośnie do wielkości kosztów związanych z opieką nad tą subpopulacją, jakie jednostki administracyjne będą ponosiły w przyszłości, z drugiej zaś strony pozwoli ustalić zapotrzebowanie na nowe miejsca pracy w lokalnej gospodarce, które mogą obejmować m.in. usługi związane z opieką i sferą wspierania osób starszych.

Redaktorzy tematyczni: Agnieszka Regulska Andrzej J. Najda 